\title{
Chronic nitrogen addition causes a reduction in soil carbon dioxide efflux during the high stem-growth period in a tropical montane forest but no response from a tropical lowland forest on a decadal time scale
}

\author{
B. Koehler ${ }^{1, *}$, M. D. Corre ${ }^{1}$, E. Veldkamp ${ }^{1}$, and J. P. Sueta ${ }^{1}$ \\ ${ }^{1}$ Büsgen Institute - Soil Science of Tropical and Subtropical Ecosystems, Georg-August-University of Göttingen, Büsgenweg \\ 2, 37077 Göttingen, Germany \\ *now at: Institute of Water and Environment, Technische Universität München, Arcisstr. 21, 80333 Munich, Germany
}

Received: 3 August 2009 - Published in Biogeosciences Discuss.: 1 September 2009

Revised: 2 December 2009 - Accepted: 3 December 2009 - Published: 11 December 2009

\begin{abstract}
Atmospheric nitrogen (N) deposition is rapidly increasing in tropical regions. We studied the response of soil carbon dioxide $\left(\mathrm{CO}_{2}\right)$ efflux to long-term experimental $\mathrm{N}$ addition $\left(125 \mathrm{~kg} \mathrm{~N} \mathrm{ha}^{-1} \mathrm{yr}^{-1}\right)$ in mature lowland and montane forests in Panama. In the lowland forest, on soils with high nutrient-supplying and buffering capacity, fine litterfall and stem-growth were neither N- nor phosphorus-limited. In the montane forest, on soils with low nutrient supplying capacity and an organic layer, fine litterfall and stemgrowth were N-limited. Our objectives were to 1) explore the influence of soil temperature and moisture on the dynamics of soil $\mathrm{CO}_{2}$ efflux and 2) determine the responses of soil $\mathrm{CO}_{2}$ efflux from an $\mathrm{N}$-rich and $\mathrm{N}$-limited forest to elevated $\mathrm{N}$ input. Annual soil $\mathrm{CO}_{2}-\mathrm{C}$ efflux was larger in the lowland $\left(15.44 \pm 1.02 \mathrm{MgCha}^{-1}\right)$ than in the montane forest $\left(9.37 \pm 0.28 \mathrm{MgCha}^{-1}\right)$. In the lowland forest, soil moisture explained the largest fraction of the variance in soil $\mathrm{CO}_{2}$ efflux while soil temperature was the main explanatory variable in the montane forest. Soil $\mathrm{CO}_{2}$ efflux in the lowland forest did not differ between the control and 9-11 yr Naddition plots, suggesting that chronic $\mathrm{N}$ input to nutrientrich tropical lowland forests on well-buffered soils may not change their $\mathrm{C}$ balance on a decadal time scale. In the montane forest, first year $\mathrm{N}$ addition did not affect soil $\mathrm{CO}_{2}$ efflux but annual $\mathrm{CO}_{2}$ efflux was reduced by $14 \%$ and $8 \%$ in the 2nd and 3rd year $\mathrm{N}$-addition plots, respectively, compared to the control. This reduction was caused by a decrease in soil $\mathrm{CO}_{2}$ efflux during the high stem-growth period of the year, suggesting a shift in carbon partitioning from below- to aboveground in the $\mathrm{N}$-addition plots in which stem diameter growth was promoted.
\end{abstract}

Correspondence to: B. Koehler

(koehlerbirgit@gmail.com)

\section{Introduction}

Tropical forests contain more than $40 \%$ of the global carbon (C) stock in vegetation (IPCC, 2007), and they account for about one third of the global soil organic $\mathrm{C}$ storage down to a depth of one meter (Jobbágy and Jackson, 2000). Every year they cycle more than $10 \%$ of the atmospheric carbon dioxide $\left(\mathrm{CO}_{2}\right)$, the most important anthropogenic greenhouse gas (IPCC, 2007), through photosynthesis, respiration and microbial decay (Malhi, 2005). A major term in this biosphere-atmosphere $\mathrm{CO}_{2}$ exchange is soil respiration, the second largest flux in the global terrestrial C cycle. Despite its central role in the global $\mathrm{C}$ cycle soil respiration remains least understood among ecosystem $\mathrm{C}$ processes (Luo and Zhou, 2006).

Soil temperature and moisture are important abiotic factors regulating $\mathrm{CO}_{2}$ production in tropical forest soils (Davidson et al., 2000; Schwendenmann et al., 2003). Generally, rates of enzymatic respiration processes increase with temperature. The common relationship with soil moisture is that $\mathrm{CO}_{2}$ efflux is small under dry conditions which depress root and microbial activity, reaches a maximal rate at intermediate soil moisture, and decreases again when anaerobic conditions prevail. Another regulating factor for soil respiration is nutrient availability, which in the case of nitrogen $(\mathrm{N})$ is drastically increasing in tropical regions due to enhanced agricultural use of $\mathrm{N}$ fertilizer, cultivation of $\mathrm{N}$-fixing plants, combustion of fossil fuels and biomass burning (Galloway et al., 2003, 2008).

One way to evaluate potential future effects of $\mathrm{N}$ deposition on tropical forests is to create $\mathrm{N}$-enriched conditions through $\mathrm{N}$ addition. Just three $\mathrm{N}$-addition experiments have evaluated $\mathrm{CO}_{2}$ efflux from tropical forest soils. Addition of $300 \mathrm{~kg} \mathrm{~N} \mathrm{ha}^{-1} \mathrm{yr}^{-1}$ to three submontane forests in Venezuela did not cause consistent trends in soil $\mathrm{CO}_{2}$

Published by Copernicus Publications on behalf of the European Geosciences Union. 
efflux in the following year (Priess and Fölster, 2001). Soil $\mathrm{CO}_{2}$ efflux was stimulated by three years of $\mathrm{N}$ addition $\left(150 \mathrm{~kg} \mathrm{~N} \mathrm{ha}^{-1} \mathrm{yr}^{-1}\right)$ to a Costa Rican lowland forest on an Ultisol soil. This raise was accompanied by an increase in the top-soil fine root biomass (Cleveland and Townsend, 2006). In contrast, two years of $\mathrm{N}$ addition at the same rate to a Chinese lowland forest on an Oxisol soil reduced soil $\mathrm{CO}_{2}$ efflux during the warm and wet growing season, while no effect was observed at lower $\mathrm{N}$-addition levels (50 and $100 \mathrm{~kg} \mathrm{~N} \mathrm{ha}^{-1} \mathrm{yr}^{-1}$; Mo et al., 2008). These differing results elucidate that responses of soil $\mathrm{CO}_{2}$ efflux to increasing $\mathrm{N}$ availability may depend on $\mathrm{N}$ loading levels and possibly soil characteristics.

To address the question of how soil $\mathrm{CO}_{2}$ efflux may respond to elevated $\mathrm{N}$ input the potential effects on root and microbial respiration need to be considered. Fine-root biomass and plant $\mathrm{C}$ allocation to mycorrhizal fungi typically decrease with rising $\mathrm{N}$ availability, which would reduce rhizosphere respiration, but to the contrary fine-root production, turnover and maintenance respiration may increase (Nadelhoffer, 2000; Norby and Jackson, 2000; Treseder, 2004). $\mathrm{N}$ addition can indirectly enhance microbial respiration if plant primary production and hence substrate availability are boosted (Luo and Zhou, 2006). The effects of $\mathrm{N}$ addition on decomposition depend on its stage: decomposition rates of light soil $\mathrm{C}$ fractions/fresh litter are accelerated but decomposition rates of heavier soil $\mathrm{C}$ fractions/humified organic matter are suppressed (Neff et al., 2002). Finally, N enrichment may ultimately change soil chemical characteristics by increasing soil acidity, cation leaching (Lohse and Matson, 2005) and aluminum mobilization into the soil solution (Likens et al., 1996) which may decrease microbial biomass (DeForest et al., 2004) and root growth (Godbold et al., 1988), consequently reducing soil respiration.

Our study reports the impact of longterm $\mathrm{N}$ addition $\left(125 \mathrm{~kg} \mathrm{Nha}^{-1} \mathrm{yr}^{-1}\right)$ on soil $\mathrm{CO}_{2}$ efflux from two speciesrich, old-growth tropical forests in Panama with contrasting $\mathrm{N}$ status: N-rich lowland forest on deeply-weathered Cambisol and Nitisol soils and N-limited montane forest on lessdeveloped Andosol soils. In the lowland forest, annual fine litterfall, leaf litter decomposition rates (Kaspari et al., 2008) and stem diameter growth were not affected by 5-6 years of $\mathrm{N}$ addition. Fine-root biomass at $0-0.2 \mathrm{~m}$ depth had not changed by 3- and 11-yr N addition (S. J. Wright, unpublished results). Soil $\mathrm{pH}$ and base saturation at $0-0.5 \mathrm{~m}$ depth were decreased after 8 years of $\mathrm{N}$ addition (Koehler et al., 2009). In the montane forest, annual fine litterfall increased during the first two years of $\mathrm{N}$ addition, and the growth rates of stems in the $0.3-0.5 \mathrm{~m}$ diameter at breast height ( $\mathrm{dbh}$ ) class were promoted by 2- and 3-yr $\mathrm{N}$ addition (Adamek et al., 2009a; Pame-Baldos, 2009). Fine-root biomass, production and turnover in organic layer and $0-0.2 \mathrm{~m}$ mineral soil did not change within 1.5-yr N addition (Adamek, 2009b). Based on these site characteristics we hypothesized that:
1. due to the increased soil acidity and resulting nutrient imbalances soil $\mathrm{CO}_{2}$ efflux in the lowland forest will be smaller from the $9-11 \mathrm{yr} \mathrm{N}$-addition than the control plots;

2. due to the increase in aboveground substrate supply for microbial decomposition soil $\mathrm{CO}_{2}$ efflux in the montane forest will be larger from the $1-3 \mathrm{yr} \mathrm{N}$-addition than the control plots.

\section{Materials and methods}

\subsection{Study area}

The lowland study site (between 25-61 m elevation) consists of an old-growth (>300 years) semi-deciduous tropical forest (Leigh et al., 1996) and is located on Gigante Peninsula $\left(9^{\circ} 06^{\prime} \mathrm{N}, 79^{\circ} 50^{\prime} \mathrm{W}\right)$ which is part of the Barro Colorado Nature Monument, Republic of Panama. On nearby Barro Colorado Island, annual rainfall (1995-2007) averages $2650 \pm 146 \mathrm{~mm}$ with a dry season from January to mid-May during which $297 \pm 40 \mathrm{~mm}$ of rainfall is recorded. Ambient $\mathrm{N}$ deposition from rainfall was $9 \mathrm{~kg} \mathrm{~N} \mathrm{ha}^{-1} \mathrm{yr}^{-1}$, measured bi-weekly from 2006 to 2007 at the shore of Gigante Peninsula near the study site. Annual air temperature averages $27.4 \pm 0.1^{\circ} \mathrm{C}$. The soil is derived from a dense basalt flow, has a heavy clay texture, and is classified as Endogleyic Cambisol in the lower and Acric Nitisol in the upper part of the landscape, respectively (FAO classification; alternatively Dystrudepts in USDA classification). The soil aluminum (Al) saturation (0-0.05 $\mathrm{m}$ depth) was increased after 8 years of $\mathrm{N}$ addition $(3.1 \pm 2.9$ and $26.6 \pm 9.1 \% \mathrm{Al}$ on cation exchange capacity in the control and $\mathrm{N}$-addition plots, respectively; $P=0.050$ ).

The montane study site (between 1200-1300 m elevation) consists of an old-growth lower montane rainforest (Grubb, 1977) and is located in the Fortuna Forest Reserve in the Cordillera Central $\left(8^{\circ} 45^{\prime} \mathrm{N}, 82^{\circ} 15^{\prime} \mathrm{W}\right)$, Chiriquí province, Republic of Panama. Mean annual rainfall is $5532 \pm 322$ mm (1997-2007), and rainfall distribution exhibits a weak seasonality (11-yr average of $244-288 \mathrm{~mm} \mathrm{month}^{-1}$ from February to April and 403-683 mm month ${ }^{-1}$ from March to January). Ambient $\mathrm{N}$ deposition from rainfall was $5 \mathrm{~kg} \mathrm{~N} \mathrm{ha}^{-1} \mathrm{yr}^{-1}$, measured bi-weekly from 2006 to 2007 at a forest clearing near the study site. The average monthly air temperature is $19^{\circ} \mathrm{C}$ from December to March and $21^{\circ} \mathrm{C}$ for all other months (annual mean $20.1 \pm 0.1^{\circ} \mathrm{C}$; 1999 2007). Monthly stem diameter increments are largest between July and December and clearly smaller in the rest of the year (Adamek et al., 2009a). The soil is derived from volcanic ash deposits, has a sandy loam texture, a substantial organic layer (median thickness of $8 \mathrm{~cm}$ ) and is classified as Aluandic Andosols (FAO) or Hapludands (USDA). Before treatment, this soil had lower $\mathrm{pH}$ and base saturation 
and larger exchangeable $\mathrm{Al}$ content than the control and 8$\mathrm{yr} \mathrm{N}$-addition lowland forest soil. 3-yr $\mathrm{N}$ addition did neither affect top soil $\mathrm{pH}(4.33 \pm 0.10$ and $4.38 \pm 0.13$ at 0 $0.05 \mathrm{~m}$ depth in the control and $\mathrm{N}$-addition plots, respectively) nor $\mathrm{pH}$ down to a depth of $0.4 \mathrm{~m}(4.76 \pm 0.14$ and $4.72 \pm 0.16$ in the control and $\mathrm{N}$-addition plots, respectively). The increase in chronic mineral soil extractable $\mathrm{NO}_{3}^{-}(0-$ $0.05 \mathrm{~m}$ ), which was statistically undistinguishable from the control during the first two years of $\mathrm{N}$ addition, was significant concerning the 3 -yr $\mathrm{N}$-addition period $(0.25 \pm 0.06$ and $0.97 \pm 0.24 \mathrm{mg} \mathrm{N} \mathrm{kg}^{-1}$ in the control and $\mathrm{N}$-addition plots, respectively; $P=0.015$ ). Detailed soil characteristics, forest structure, and temporal patterns of soil mineral $\mathrm{N}$ concentrations (in 2006 and 2007) for both sites can be found in Koehler et al. (2009).

\subsection{Experimental design}

In the lowland, our study was conducted in the only ongoing chronic nutrient addition experiment in old-growth forest. The experiment includes $\mathrm{N}$-addition and control plots laid out in four replicates across a 26.6 ha area in a stratified random design. $\mathrm{N}$ addition started in June 1998. In the montane forest, the experiment was set up in a paired-plots random design with four replicates. $\mathrm{N}$ addition started in February 2006. At both sites, each plot is $40 \times 40 \mathrm{~m}$ in size and plots are separated by at least $40 \mathrm{~m}$ distance. The $\mathrm{N}$ addition plots received $125 \mathrm{~kg}$ urea- $\mathrm{N} \mathrm{ha}^{-1} \mathrm{yr}^{-1}$ split in four equal applications. In the lowland forest, $\mathrm{N}$ was applied during wet season with six to eight weeks between applications. In the montane forest, the $\mathrm{N}$ applications were spread during the year with at least seven weeks time-lag (for details please see Koehler et al. (2009)).

\subsection{Soil $\mathrm{CO}_{2}$ efflux, temperature and moisture measurements}

From January 2006 to January 2009 we measured soil $\mathrm{CO}_{2}$ efflux, soil temperature and soil moisture every six weeks on all plots and more intensively on the $\mathrm{N}$-addition plots (two to five times within a six week period following $\mathrm{N}$ addition). In each plot, four permanent chamber bases were inserted $\sim 0.02 \mathrm{~m}$ into the soil in a stratified random design along two perpendicular $20 \mathrm{~m}$ long transects that cross the plot's central point. Therefore, all chambers were surrounded (buffered) by at least $10 \mathrm{~m}$ of forest receiving the same treatment. Soil $\mathrm{CO}_{2}$ efflux was measured during the day using vented static chambers (area $0.04 \mathrm{~m}^{2}$, height $0.25 \mathrm{~m}$ ). A study on nearby Barro Colorado Island had indicated that day and night soil $\mathrm{CO}_{2}$ efflux was statistically undistinguishable (Kursar, 1989). Four gas samples $(100 \mathrm{~mL}$ each) were removed at 2,12, 22 and $32 \mathrm{~min}$ after chamber closure and stored in pre-evacuated glass containers with a teflon stopcock. Gas samples were analyzed using a gas chromatograph (Shimadzu GC-14B, Germany) equipped with an elec- tron capture detector (Loftfield et al., 1997) which was calibrated with three to four standard gases $(360,706,1505$ and 5012 ppm CO ${ }_{2}$, Deuste Steininger GmbH, Mühlhausen, Germany). Gas fluxes were calculated from the concentration increase in the chamber versus time, and were adjusted for air temperature and atmospheric pressure measured at the time of sampling. To account for the decreasing diffusion gradient over time caused by the chamber feedback we fitted both a linear and a quadratic regression model if $\mathrm{CO}_{2}$ concentrations increased asymptotically (Wagner et al., 1997). We chose the statistically more adequate model based on the Akaike Information Criterion. The quadratic model was used in $29 \%$ of the gas flux calculations. If the concentration increase leveled out but the quadratic model was statistically inferior we excluded the respective last data points and calculated the flux based on a linear model. This data screening and calculation procedures provide that we minimized underestimations which may occur if a linear model was uncritical applied to static chamber flux data (e.g. Livingston et al., 2006). Two pre-treatment measurements in the montane forest indicated that the initial soil $\mathrm{CO}_{2}$-efflux did not differ between the control plots and those that had been randomly assigned to the $\mathrm{N}$-addition treatment. We do not have pretreatment measurements of soil $\mathrm{CO}_{2}$ efflux from the 9-11$\mathrm{yr} \mathrm{N}$-addition plots of the lowland forest. The annual gaseous $\mathrm{C}$ losses were approximated by applying the trapezoid rule on time intervals between measured flux rates, assuming constant flux rates per day.

Parallel to gas sampling, soil temperature was measured at $0.05 \mathrm{~m}$ depth near each of the four chamber bases per plot. For soil moisture, four samples of $0-0.05 \mathrm{~m}$ mineral soil (and additionally from the organic layer at the montane site) were collected within the inner $10 \times 10 \mathrm{~m}$ of each plot and pooled. A subsample was oven-dried at $105^{\circ} \mathrm{C}$ for $24 \mathrm{~h}$. Soil moisture is expressed as percentage of water-filled pore space, assuming a particle density of $2.65 \mathrm{~g} \mathrm{~cm}^{-3}$ for mineral soil (Linn and Doran, 1984) and of $1.4 \mathrm{~g} \mathrm{~cm}^{-3}$ for organic layer (Breuer et al., 2002).

\subsection{Statistical analyses and calculations}

If data sets were rightly skewed a square-root or logarithmic transformation was applied before analysis. If data sets were left-skewed a quadratic or cubic transformation was applied before analysis. Regression analyses (on treatment means) were conducted to investigate the influence of soil moisture and temperature on soil $\mathrm{CO}_{2}$ efflux. For the lowland forest, the data of the control and $\mathrm{N}$-addition plots were pooled to increase the robustness of parameter estimates. This was justified by their comparable soil $\mathrm{CO}_{2}$ efflux, temperature and moisture (see Sect. 3). In multiple regression or if including squared terms the explanatory variables $x$ were mean-centered and normalized before analysis $\left[x^{*}=(x\right.$-mean $(x)) /$ standard error $\left.(x)\right]$. Multiple regression analyses were conducted by first fitting the maximal model 
Lowland forest
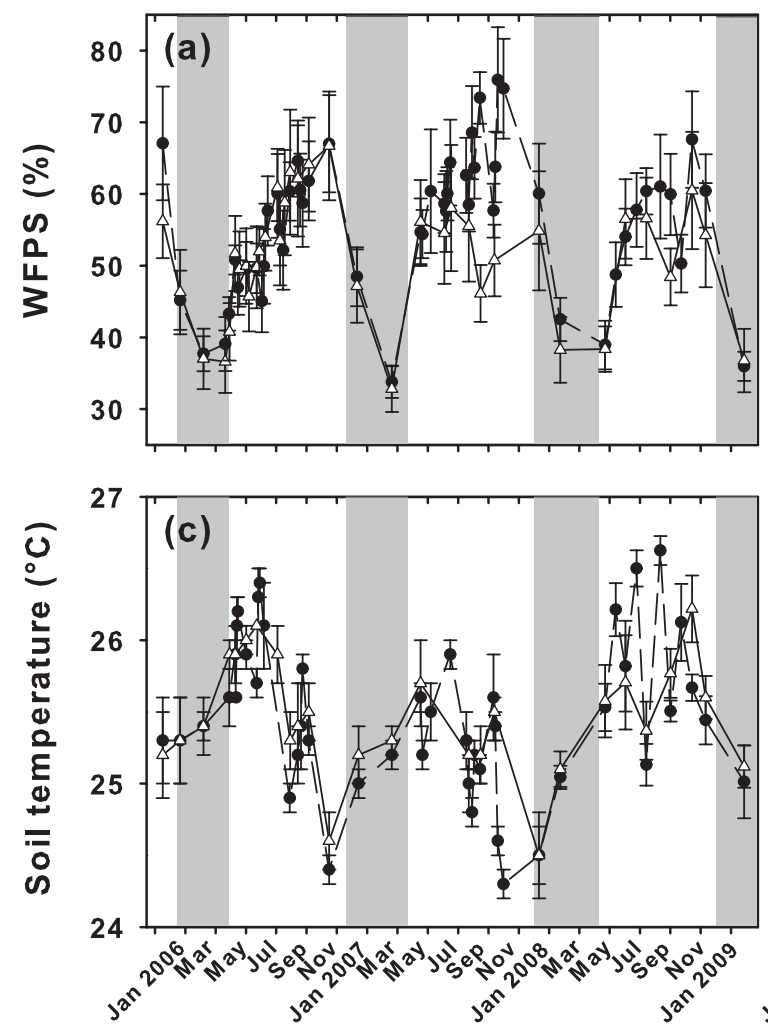

Montane forest
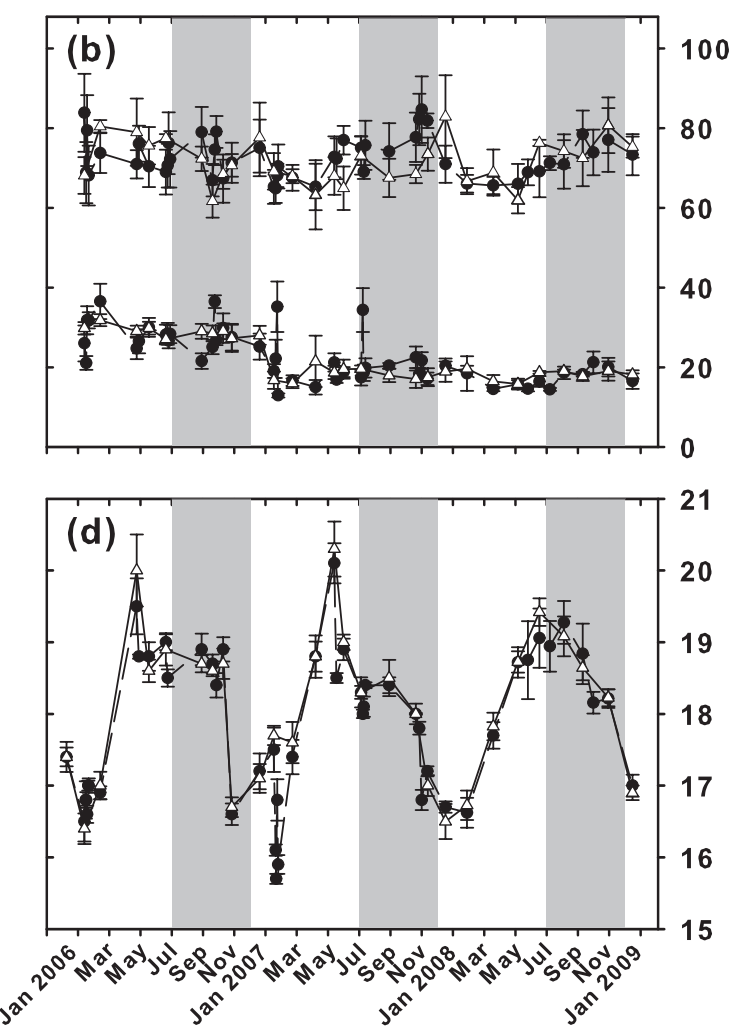

Fig. 1. Mean $( \pm$ SE, $n=4)$ water-filled pore space (WFPS) and soil temperature at $0.05 \mathrm{~m}$ depth in the control $(\Delta)$ and $\mathrm{N}$-addition $(\bullet)$ lowland (a and $\mathbf{c}$ ) and montane (b and $\mathbf{d}$ ) forest. For WFPS in the montane forest, the upper and lower values are for the $0-0.05 \mathrm{~m}$ mineral soil and organic layer, respectively. Grey shading marks the dry seasons in the lowland forest, and the high stem-growth periods in the montane forest.

(containing all linear, squared and interaction terms) and progressing to the minimal adequate model through a series of single-term deletions based on F-tests (Crawley, 2002). Variance inflation factors as multicollinearity measure were $<2$ in all models. Model significance was assessed by regression analysis of variance. Linear mixed effects models (on plot means) were used to test for the "fixed effect" of treatment ( $\mathrm{N}$ addition), site (lowland vs. montane forest) or season on the time-series of the response variables (i.e. the repeated measurements of soil $\mathrm{CO}_{2}$ efflux, soil temperature and waterfilled pore space). The spatial replication nested in time was included as "random" effect. The models were specified as explained in Koehler et al. (2009) and the significance of the fixed effect was evaluated using analysis of variance (Crawley, 2002). For soil characteristics, treatment effects and/or differences between sites were assessed using independent t-tests. In all analyses concerning soil $\mathrm{CO}_{2}$ efflux, only the fluxes measured at least 6 weeks after an $\mathrm{N}$-application were considered (see Sect. 3.3). Effects were considered significant if $p$-value $\leq 0.05$. For the montane forest, we calculated the ratio of soil $\mathrm{CO}_{2}$ efflux to mean monthly stem diameter growth (0.3-0.5 $\mathrm{m}$ dbh class) per plot based on the growth data reported in Adamek et al. (2009a) and PameBaldos (2009). If the mean stem diameter growth in a plot was effectively zero $\left(<0.1 \mathrm{~mm}\right.$ month $\left.^{-1}\right)$ these ratios were excluded as they were artificially large ( $>4.5$ times the interquartile range). By dividing the plot ratios with the maximal value (normalization) they were converted to a dimensionless measure. Mean values in the text are given with \pm 1 standard error, regression parameter estimates are given with the $95 \%$ confidence level. Analyses were conducted using R 2.9.0 (R Development Core Team, 2009).

\section{Results}

\subsection{Water-filled pore space and temperature in the con- trol forest soils}

Water-filled pore space (WFPS) showed a seasonal pattern in the lowland forest where it varied by $34 \%$ between dry and wet seasons (Fig. 1a). In the montane forest, WFPS was larger in the mineral soil than in the organic layer. WFPS varied less throughout the year than in the lowland (21\% and $16 \%$ in mineral soil and organic layer, respectively; Fig. 1b). 


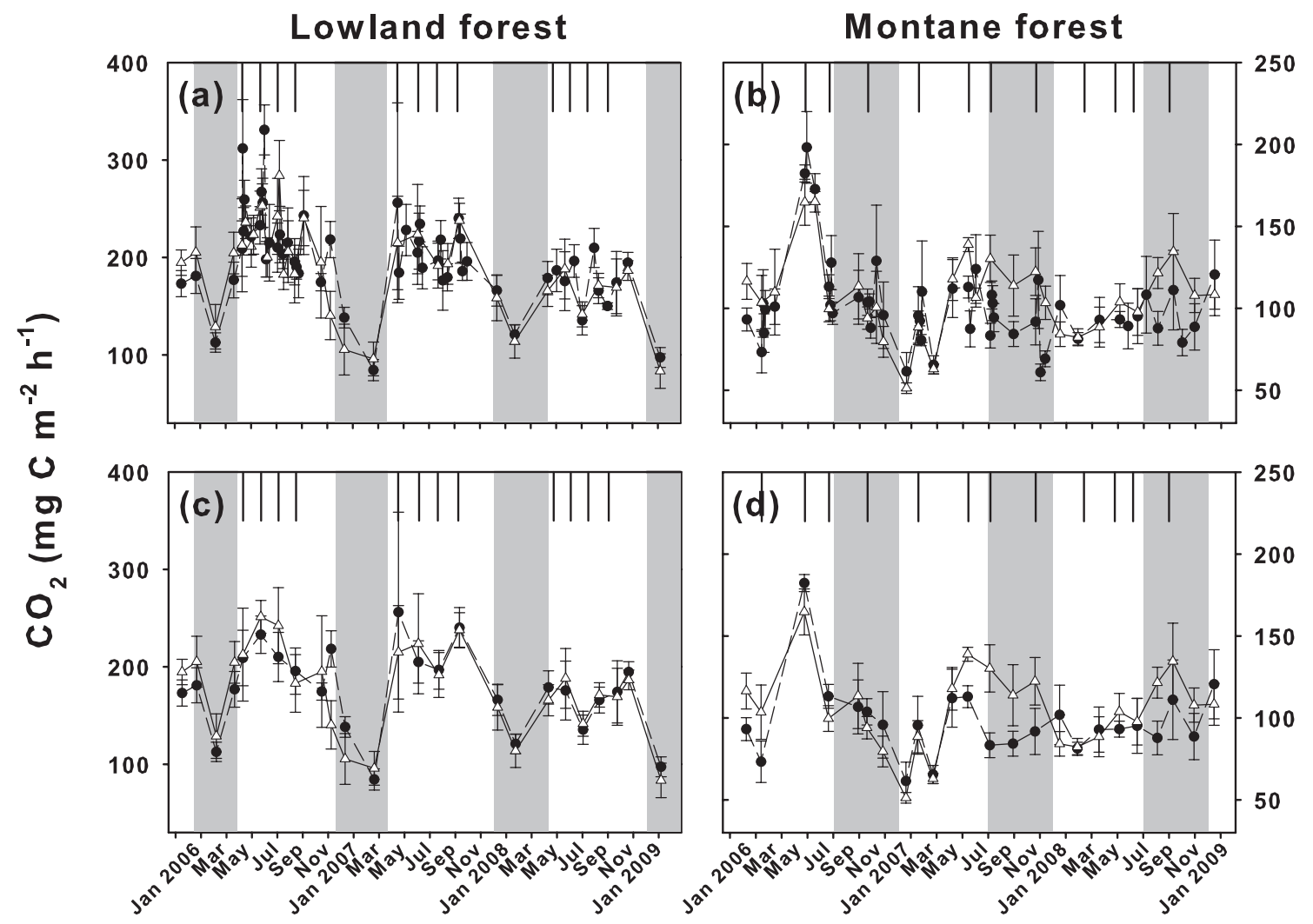

Fig. 2. Mean $( \pm \mathrm{SE}, n=4)$ soil $\mathrm{CO}_{2}$ efflux from the control $(\Delta)$ and $\mathrm{N}$-addition $(\bullet)$ lowland (a and $\left.\mathbf{c}\right)$ and montane (b and d) forest. Upper panels include the transitory fertilization effects, and lower panels show only the chronic fluxes at least 6 weeks after an $\mathrm{N}$ addition. Black vertical lines indicate dates of $\mathrm{N}$ addition. Grey shadings mark the dry seasons and the high stem-growth periods in the lowland and montane forest, respectively.

In contrast, soil temperature at $0.05 \mathrm{~m}$ depth varied seasonally by only $1.7^{\circ} \mathrm{C}$ (annual mean of $25.5^{\circ} \mathrm{C}$ ) in the lowland (Fig. 1c) but by $3.8^{\circ} \mathrm{C}$ (annual mean of $18.1^{\circ} \mathrm{C}$ ) in the montane forest (Fig. 1d). An unusually low-rainfall period in the montane forest (February to April 2007 with $~ 40 \%$ less rain than the 11-yr average) caused a reduction in the WFPS in both mineral soil and organic layer. With the onset of higher rainfall the WFPS re-increased in the mineral soil while it remained smaller in the organic layer until the end of the study (Fig. 1b). WFPS and soil temperature did not differ between control and $\mathrm{N}$-addition plots at either site.

\subsection{Soil $\mathrm{CO}_{2}$ efflux of the control forests}

Soil $\mathrm{CO}_{2}$ effluxes were larger from the lowland $\left(189.60 \pm 7.95 \mathrm{mg} \mathrm{C} \mathrm{m}^{-2} \mathrm{~h}^{-1}\right)$ than the montane forest (107.29 $\pm 4.68 \mathrm{mg} \mathrm{C} \mathrm{m}^{-2} \mathrm{~h}^{-1}, \quad P=0.004$, Table 1). In the lowland, they ranged between $83.45 \pm 17.69$ and $283.99 \pm 36.08 \mathrm{mg} \mathrm{C} \mathrm{m}^{-2} \mathrm{~h}^{-1}$ and displayed a distinct seasonal pattern, averaging smaller during dry season $\left(136.96 \pm 16.82 \mathrm{mg} \mathrm{C} \mathrm{m}^{-2} \mathrm{~h}^{-1}\right)$ than during wet season $\left(205.20 \pm 6.60 \mathrm{mg} \mathrm{C} \mathrm{m}^{-2} \mathrm{~h}^{-1}, \quad P<0.001\right.$, Fig. 2a, c). $26.18 \pm 1.50 \%$ of the annual $\mathrm{CO}_{2}$ efflux occurred during the $\sim 130$ days of dry season. WFPS explained a larger fraction of the variance in soil $\mathrm{CO}_{2}$ efflux than soil temperature. Soil $\mathrm{CO}_{2}$ effluxes were maximal at an intermediate WFPS and decreased below and above this value (Fig. 3a). Based on a regression tree moisture limitation of soil $\mathrm{CO}_{2}$ production took place below a WFPS of $\sim 38 \%$. A regression between soil $\mathrm{CO}_{2}$ efflux and temperature illustrates that temperature was only a relevant explanatory variable if $\mathrm{CO}_{2}$ production was not limited by low soil moisture (Fig. 4a; please note that the linear regression slope would not differ if the control and $\mathrm{N}$-addition plots would be analyzed separately). Accordingly, the minimal adequate multiple regression model contains not only WFPS (and its quadratic term) and soil temperature but also the interaction-term of both factors (parameter estimates $\pm 95 \% \mathrm{CI}$ ):

$$
\begin{aligned}
\mathrm{CO}_{2} & =189.07( \pm 12.18)+3.24( \pm 1.51) T^{*} \\
& +2.09( \pm 1.18) \text { WFPS }^{*}-0.22( \pm 0.14) \text { WFPS }^{* 2} \\
& -0.28( \pm 0.21) \text { WFPS }^{*} T^{*}
\end{aligned}
$$

where $\mathrm{CO}_{2}$ is mean soil $\mathrm{CO}_{2}$ efflux $\left(\mathrm{mg} \mathrm{C} \mathrm{m}^{-2} \mathrm{~h}^{-1}\right), T$ is soil temperature at $0.05 \mathrm{~m}$ depth $\left({ }^{\circ} \mathrm{C}\right)$, WFPS is waterfilled pore space $(\%)$ and $*$ indicates that the variable was 
Table 1. Annual soil $\mathrm{CO}_{2}$ efflux $\left(\mathrm{Mg} \mathrm{Cha}^{-1}\right.$, mean $\left.\pm \mathrm{SE}, n=4\right)$ for the control and $\mathrm{N}$-addition plots. Only $\mathrm{CO}_{2}$ fluxes measured at least 6 weeks after an $\mathrm{N}$ addition were included (see Sect. 3.3).

\begin{tabular}{llccc}
\hline Site & Treatment & 2006 & 2007 & 2008 \\
\hline \multirow{2}{*}{ Montane } & Control & $9.93 \pm 0.62$ & $9.17 \pm 0.55$ & $9.01 \pm 0.55$ \\
& $1-3$-yr N addition & $\left(11.03 \pm 0.51^{*}\right)$ & $7.88 \pm 0.35$ & $8.30 \pm 0.22$ \\
Lowland & Control & $17.12 \pm 1.59$ & $15.63 \pm 0.91$ & $13.59 \pm 1.34$ \\
& $9-11$-yr N addition & $16.30 \pm 0.92$ & $15.45 \pm 0.87$ & $13.84 \pm 0.93$ \\
\hline
\end{tabular}

* The two pre-treatment measurements from January and February 2006 (Fig. 2b, d) were excluded. Note that this annual value is biased towards an overestimation because the high $\mathrm{CO}_{2}$ efflux measured in May 2006 is not representative for the integration time it represents.
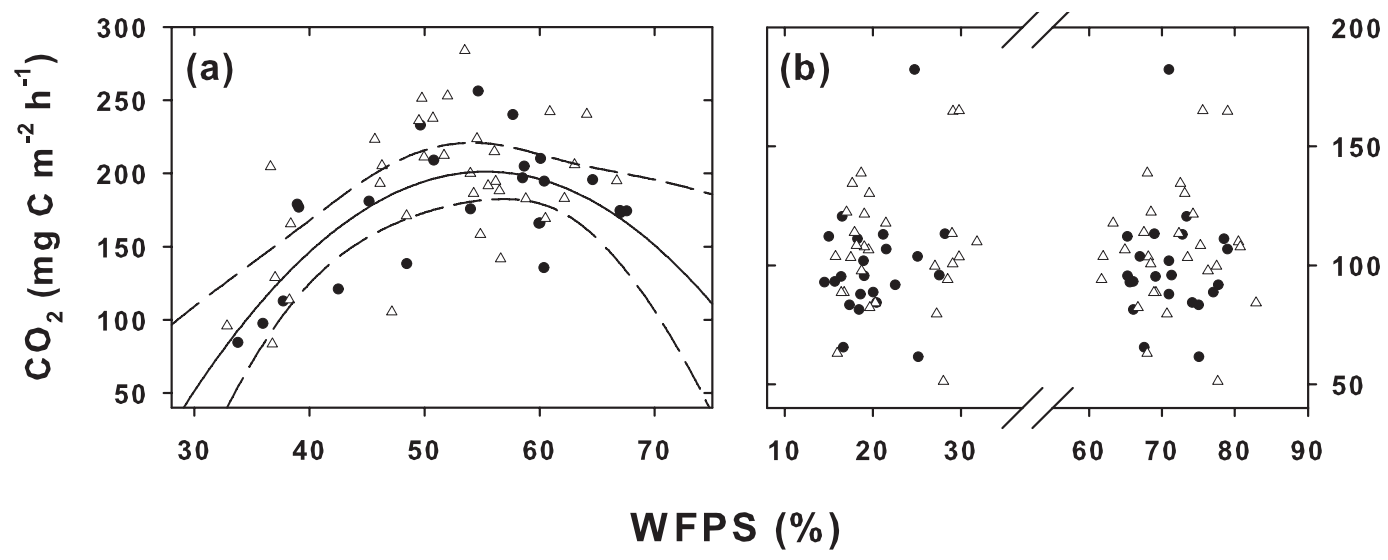

Fig. 3. Regression analyses (parameter estimates $\pm 95 \% \mathrm{CI}$ ) between mean water-filled pore space (WFPS) and $\mathrm{CO}_{2}$ efflux of the control $(\Delta)$ and $\mathrm{N}$-addition $(\bullet)$ plots for the (a) lowland $\left[y=204.45( \pm 13.06)+1.78( \pm 1.32) x^{*}-0.35( \pm 0.16) x^{* 2}, R^{2}=0.42, n=60, P<0.001\right.$, * denotes that the variable $x$ was mean-centered and normalized before analysis] and (b) montane forest (no significant relationships). For the lowland forest, the analysis was conducted on the pooled data of the control and N-addition plots (see Sect. 2.4). For the montane forest, the analysis was conducted separately for the control and $\mathrm{N}$-addition plots. Data points to the left and right of the $\mathrm{x}$-axis break are for the organic layer and mineral soil, respectively. For both sites, only $\mathrm{CO}_{2}$ fluxes measured at least 6 weeks after an $\mathrm{N}$ addition were included (see Sect. 3.3).

mean-centered and normalized before analysis $\left(n=47, R^{2}=\right.$ $0.65, P<0.001)$.

Soil $\mathrm{CO}_{2}$ effluxes from the montane forest varied less than in the lowland, between $51.27 \pm 3.22$ and $165.01 \pm 6.26 \mathrm{mg} \mathrm{C} \mathrm{m}^{-2} \mathrm{~h}^{-1}$. In 2007 and 2008 they were larger during the high stem-growth period than during the other months $(P=0.001$, Fig. $2 \mathrm{~b}$, d). No relationship was detected between soil $\mathrm{CO}_{2}$ efflux and WFPS (in either organic layer or mineral soil, Fig. 3b), while soil $\mathrm{CO}_{2}$ efflux increased with increasing soil temperature (Fig. 4b).

\subsection{Effects of elevated $\mathrm{N}$ input on the chronic soil $\mathrm{CO}_{2}$ efflux}

Often, during the time when soil extractable $\mathrm{N}$ concentrations were artificially elevated within a month following an $\mathrm{N}$ application (Koehler et al., 2009), transitory peaks occurred in soil $\mathrm{CO}_{2}$ efflux (Fig. 2a, b). Because we are interested in evaluating the ultimate long-term effects of an $\mathrm{N}$-enriched soil $\mathrm{N}$-cycle on soil $\mathrm{CO}_{2}$ efflux we excluded these transitory effects from the subsequent analyses and only considered the "chronic" fluxes measured at least 6 weeks after an $\mathrm{N}$ application, which are reported in the following. In the lowland forest, soil $\mathrm{CO}_{2}$ efflux did not differ between the control and 9-11-yr N-addition plots $\left(176.59 \pm 8.64 \mathrm{mg} \mathrm{C} \mathrm{m}^{-2} \mathrm{~h}^{-1}\right.$, Fig. 2c). In the montane forest, soil $\mathrm{CO}_{2}$ efflux did not differ between the control and $\mathrm{N}$-addition plots during the first year of $\mathrm{N}$ addition $\left(112.14 \pm 11.53 \mathrm{mg} \mathrm{C} \mathrm{m}^{-2} \mathrm{~h}^{-1}\right)$. In the second year of $\mathrm{N}$ addition, soil $\mathrm{CO}_{2}$ efflux was smaller from the $\mathrm{N}$-addition than the control plots during the high stemgrowth period $(P=0.025)$. These diminished $\mathrm{CO}_{2}$ effluxes resulted in $14 \%$ reduction of the mean annual soil $\mathrm{CO}_{2}$ efflux relative to the control (Fig. 5a, Table 1). A reduction of soil $\mathrm{CO}_{2}$ efflux from the $\mathrm{N}$-addition plots was observable during the high stem-growth period in the third year of $\mathrm{N}$ addition as well, but these fluxes were statistically undistinguishable from the controls ( $P=0.163$; Figs. $2 \mathrm{~d}$, 5b, Table 1). The ratio of soil $\mathrm{CO}_{2}$ efflux to monthly stem diameter growth $(0.3-0.5 \mathrm{~m}$ dbh class) was smaller in the $\mathrm{N}$-addition than the 


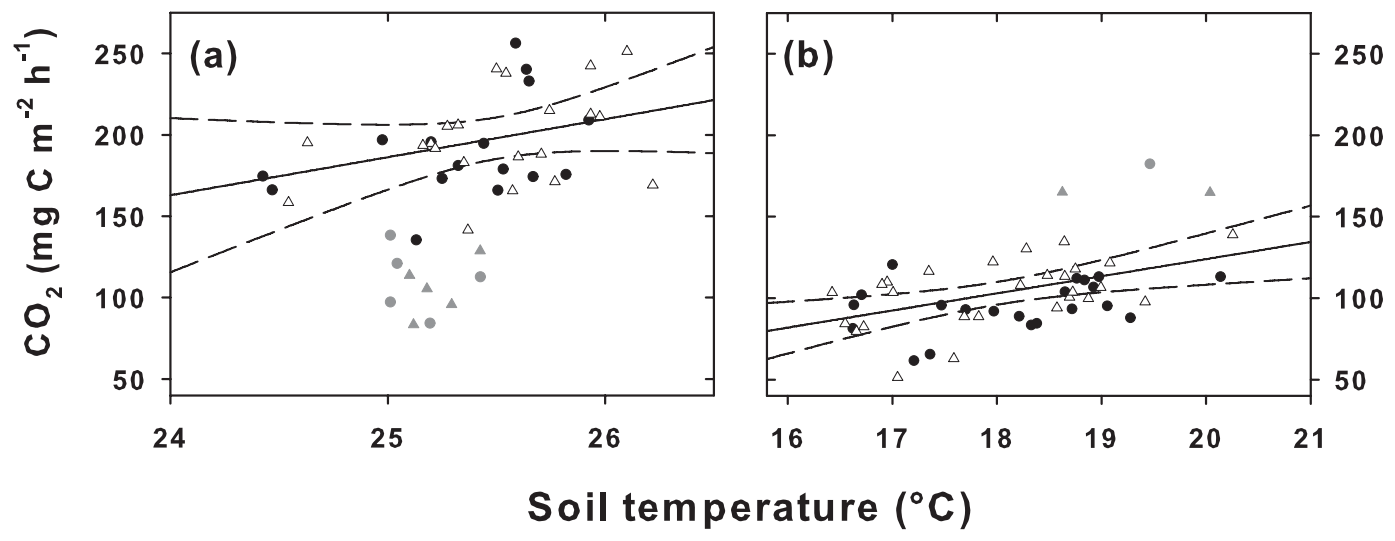

Fig. 4. Linear regressions (parameter estimates $\pm 95 \% \mathrm{CI})$ between mean soil temperature $\left(0.05 \mathrm{~m}\right.$ depth) and $\mathrm{CO}_{2}$ efflux of the control $(\Delta)$ and N-addition $(\bullet)$ plots for the (a) lowland $\left[y=-484.45( \pm 551.25)+26.71( \pm 21.67) x, R^{2}=0.15, n=51, P=0.017\right]$ and $(\mathbf{b})$ montane forest [control plots: $y=-86.34( \pm 128.13)+10.51( \pm 7.10) x, R^{2}=0.27, n=26, P=0.005$; N-addition plots: no significant relationship]. For the lowland forest, the analysis was conducted on the pooled data of the control and N-addition plots (see Sect. 2.4) and excluded ten data points (grey) of which soil $\mathrm{CO}_{2}$ production was limited by low soil moisture content. For the montane forest, the analysis was conducted separately for the control and $\mathrm{N}$-addition plots and excluded the three large $\mathrm{CO}_{2}$ fluxes from May 2006 (grey; Fig. 2b, d). For both sites, only CO fluxes measured at least 6 weeks after an $\mathrm{N}$ addition were included (see Sect. 3.3).

control plots ( $P=0.018$; Fig. 6). Considering the time period since this effect emerged (i.e. May 2007) until the end of the study the reduction averaged $16 \pm 3 \%$. Differing from the controls, soil temperature did not explain a significant fraction of the variance in soil $\mathrm{CO}_{2}$ efflux from the $\mathrm{N}$-addition plots (Fig. 4b; $R^{2}=0.13, n=21, P=0.105$ ).

\section{Discussion}

\subsection{Soil moisture and temperature regulation on soil $\mathrm{CO}_{2}$ efflux from the control forests}

The importance of soil moisture and temperature in regulating soil $\mathrm{CO}_{2}$ efflux, through their influence on $\mathrm{CO}_{2}$ production by microbial and root respiration, differed between the lowland and montane forests. We did not calculate apparent $Q_{10}$ values of soil $\mathrm{CO}_{2}$ efflux because in the field the influence of plant phenology and soil temperature variation at an arbitrarily chosen depth can not be separated (Davidson et al., 2006). The influence of plant phenology on soil respiration is mainly due to different timing of litterfall, root growth, and root turnover (Curiel Yuste et al., 2004). In the lowland forest, the seasonality in rainfall and thus in soil moisture strongly influences plant phenology as well as decomposition. Leaf fall peaks during dry season when decomposition is limited by low soil moisture (Cornejo et al., 1994), while nutrient mineralization rates (except for potassium) are much greater during wet than during dry season (Yavitt et al., 2004). Fine root productivity is also restricted by low water supply and hardened soil during dry season. Fine roots

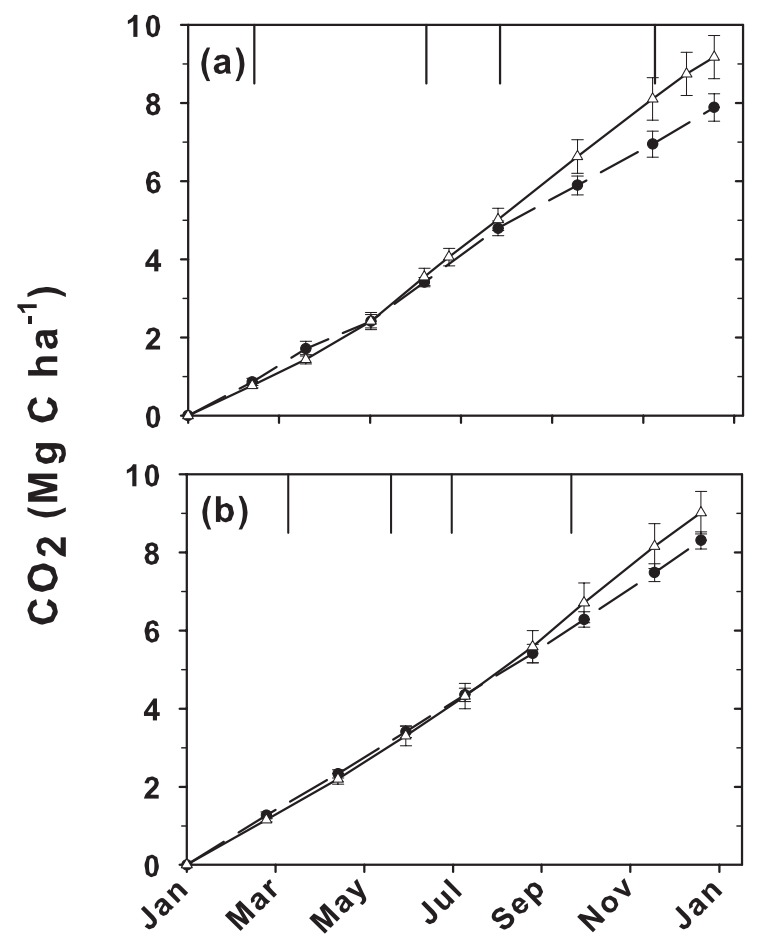

Fig. 5. Mean $( \pm \mathrm{SE}, n=4)$ cumulative soil $\mathrm{CO}_{2}$ efflux from the control $(\Delta)$ and N-addition (•) montane forest in (a) 2007 (2-yr N addition) and (b) 2008 (3-yr N addition). Only $\mathrm{CO}_{2}$ fluxes measured at least 6 weeks after an $\mathrm{N}$ addition were included (see Sect. 3.3). Black vertical lines indicate dates of $\mathrm{N}$ addition. 


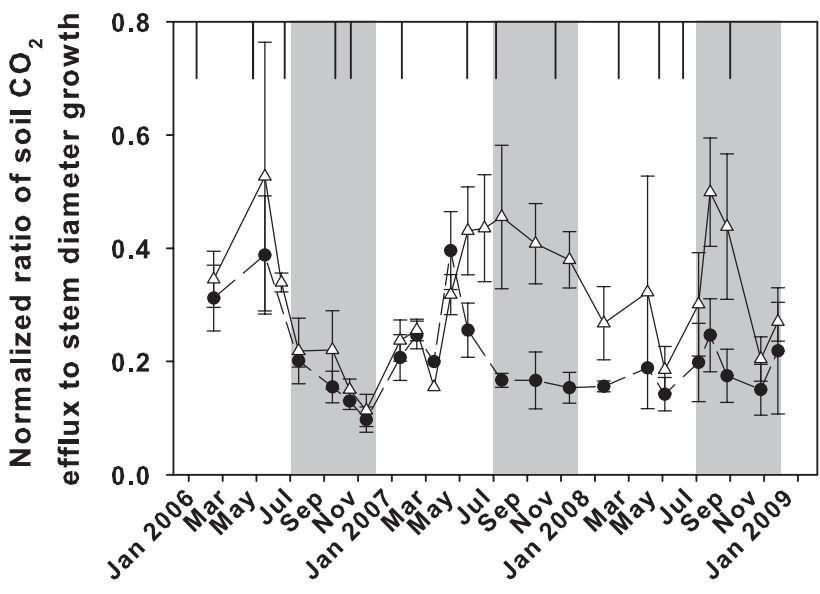

Fig. 6. Mean ( $\pm \mathrm{SE}, n=4)$ normalized ratio of soil $\mathrm{CO}_{2}$ efflux to monthly stem growth of trees with $0.3-0.5 \mathrm{~m}$ diameter at breast height from the control $(\Delta)$ and $\mathrm{N}$-addition $(\bullet)$ montane forest. Black vertical lines indicate dates of $\mathrm{N}$ addition. Grey shadings mark the high stem-growth periods. Only $\mathrm{CO}_{2}$ fluxes measured at least 6 weeks after an $\mathrm{N}$ addition were included (see Sect. 3.3).

grow rapidly during the first half of wet season and much less during the remainder of the year, and maximum fine root biomass occurs in the transition between dry and wet season (Cavelier et al., 1999; Yavitt and Wright, 2001). The soil $\mathrm{CO}_{2}$ efflux reflected these patterns in decomposition and plant phenology. The effluxes were largest in the first half of wet season and decreased thereafter, reaching their minimum at the end of dry season (Fig. 2c). The regression analyses confirmed the strong influence of soil moisture on soil $\mathrm{CO}_{2}$ efflux (Fig. 3a). The interaction term between soil moisture and temperature in the multiple regression model (Eq. 1) reflects that soil $\mathrm{CO}_{2}$ efflux only increased with temperature if $\mathrm{CO}_{2}$ production was not limited by low soil moisture content (Fig. 4a). The annual soil $\mathrm{CO}_{2}$ efflux is comparable to values reported from other old-growth tropical lowland forests (Raich and Schlesinger, 1992).

In the montane forest, only soil temperature explained a significant fraction of the variance in soil $\mathrm{CO}_{2}$ efflux. This site receives almost double annual rainfall than the lowland forest and has lower air and soil temperatures. The fine litterfall exhibits a seasonal pattern with larger amounts falling in the windier period between $\sim$ November and February (Adamek et al., 2009a). In spite of the availability of fresh substrate for microbial decomposition, soil $\mathrm{CO}_{2}$ effluxes were smaller during this colder period of the year (Figs. 1d, 2d). This suggests that the increase of $\mathrm{CO}_{2}$ efflux in May was prompted by the simultaneously rising soil temperature, and that $\mathrm{CO}_{2}$ production was hampered by low temperatures during $\sim$ February to April. However, the seasonal pattern in soil $\mathrm{CO}_{2}$ efflux probably resulted in part from changes in root biomass and production. If these were largely temperature-independent and mainly regulated by a different factor (e.g. photosynthetically active radiation) they may have confounded the increase of soil $\mathrm{CO}_{2}$ efflux with temperature. The annual soil $\mathrm{CO}_{2}$ efflux is comparable to values reported from other old-growth tropical montane forests (Raich, 1998; Priess and Fölster, 2001). In the lowland forest, where soil temperature varies little throughout the year, seasonal changes in soil $\mathrm{CO}_{2}$ efflux were mainly triggered by differences in soil moisture while the opposite seemed to be the case in the montane forest.

\subsection{Effects of $\mathrm{N}$ addition on soil $\mathrm{CO}_{2}$ efflux from the lowland forest}

Soil $\mathrm{CO}_{2}$ efflux did not differ between the control and Naddition plots in the lowland forest (Fig. 2c, Table 1) and, in combination with results from studies on fine roots, litterfall and decomposition, this suggests that both root and microbial respiration were resilient to the observed $\mathrm{N}$-induced changes in soil chemical characteristics. Our measured bulk soil $\mathrm{CO}_{2}$ efflux does not allow us to distinguish between the $\mathrm{CO}_{2}$ sources. It is possible that an increase in $\mathrm{CO}_{2}$ production from one source was offset by a decrease from the other source. However, our assumption that neither root nor microbial respiration were strongly influenced by chronic $\mathrm{N}$ addition is in line with previous findings: 1) fine root biomass in $0-0.2 \mathrm{~m}$ depth had not changed by $3-$ and $11-\mathrm{yr} \mathrm{N}$ addition (S. J. Wright, unpublished results) and 2) neither annual leaf litterfall nor leaf litter mass loss rates were influenced by 6-yr $\mathrm{N}$ addition (Kaspari et al., 2008).

Our result that elevated $\mathrm{N}$-input did not affect soil $\mathrm{CO}_{2}$ efflux contrasts the findings from an $\mathrm{N}$-addition study in an $\mathrm{N}$-rich Costa Rican lowland forest on an Ultisol soil. In that study, laboratory experiments with root-free soil showed that microbial respiration was not altered by $\mathrm{N}$ addition (Cleveland et al., 2006; Cleveland and Townsend, 2006). In the field, however, soil $\mathrm{CO}_{2}$ efflux was boosted by 3 -yr addition of $150 \mathrm{~kg} \mathrm{Nha}^{-1} \mathrm{yr}^{-1}$. This rise was partly attributed to a parallel increase in the top-soil fine root biomass. A possible explanation for the contrasting results in our study and theirs is that root responses on a smaller scale of nutrient manipulation $(5 \times 5 \mathrm{~m}$ treatment plots in Costa Rica) may differ from and might not reflect - responses to fertilization across entire root systems occupying larger soil volumes $(40 \times 40 \mathrm{~m}$ treatment plots in this study; Raich et al., 1994; Ostertag, 2001; Cleveland and Townsend, 2006).

The fact that soil $\mathrm{CO}_{2}$ efflux did not change under chronic $\mathrm{N}$ addition despite alterations in soil chemical traits (i.e. decrease in $\mathrm{pH}$ and base saturation, increase in $\mathrm{Al}$ saturation) may be explained by the initial soil characteristics of our site. Our soils have a higher $\mathrm{pH}$, effective cation exchange capacity and base saturation than Ferralsols/Oxisols (Koehler et al., 2009), and a very low Al saturation. The supply of available phosphorus $(\mathrm{P})$ is possibly sufficient, i.e. litterfall and stem diameter growth did not respond to P-addition (S. J. Wright, unpublished results). Data 
on dissolved ions indicate that active weathering occurs in both the control and chronic N-addition plots (M. D. Corre, unpublished results). After 8 years of $\mathrm{N}$ addition, the top soil $\mathrm{pH}(4.5 \pm 0.1)$ was still in the upper part of the range wherein acidity is neutralized by $\mathrm{Al}$ solubilization from silicates and hydrous oxides (pH 3-5, Van Breemen et al., 1983). Therefore, despite the observed increase in $\mathrm{Al}$ saturation, the $\mathrm{Al}$ concentrations may not have reached a level where toxicity effects on roots and microbial biomass are expressed. After a decade of $\mathrm{N}$ addition, the good nutrient-supplying and buffering capacity in our soils still mitigates acidity- or Al-induced reductions of soil respiration.

With $\mathrm{N}$ addition ongoing we expect that our studied forest will eventually exhibit a decline in soil $\mathrm{CO}_{2}$ efflux, as reported from $\mathrm{N}$-enriched temperate forests (Bowden et al., 2004) and an N-saturated tropical lowland forest on an Oxisol soil in China. The Chinese site has been receiving high atmospheric deposition of $>30 \mathrm{~kg} \mathrm{Nha}^{-1} \mathrm{yr}^{-1}$ for several decades. Aboveground primary production (fine litterfall and stem growth) was not affected by $\mathrm{N}$ addition (Mo et al., 2008; J. Mo, personal communication). Already the control top soil $\mathrm{pH}(3.76 \pm 0.01)$ is in the lower part of the Al-buffer range and hence a progressing $\mathrm{N}$-induced acidification may increasingly manifest Al-toxicity on roots and microbial biomass. The observed decrease in soil $\mathrm{CO}_{2}$ efflux within 2-yr experimental addition of $150 \mathrm{~kg} \mathrm{~N} \mathrm{ha}^{-1} \mathrm{yr}^{-1}$ was indeed accompanied by a decline in microbial biomass, fine root biomass (both in the top soil) and litter decomposition rates (Mo et al., 2006; 2008). Our finding that soil $\mathrm{CO}_{2}$ efflux did not change with chronic $\mathrm{N}$ addition to an old-growth tropical lowland forest differs from both previous studies but this is explicable by scale-related differences in root responses to $\mathrm{N}$ addition on the one hand and site-specific soil characteristics as well as exposure time and $\mathrm{N}$-loading level on the other hand.

\subsection{Effects of $\mathrm{N}$ addition on soil $\mathrm{CO}_{2}$ efflux from the montane forest}

Soil $\mathrm{CO}_{2}$ efflux did not differ between the control and 1yr $\mathrm{N}$-addition plots but was diminished during the high stemgrowth period in the second and third year of $\mathrm{N}$ addition (statistically distinguishable only in the second year, Fig. 2d). Soil $\mathrm{CO}_{2}$ efflux was positively correlated with soil temperature in the control plots while the same relationship was not significant in the N-addition plots (Fig. 4b). Based only on the regression statistics we would not claim that this indicates a reduction of temperature sensitivity, however, it is a hypothesis which deserves further investigation. As 3$\mathrm{yr} \mathrm{N}$ addition did not alter the soil $\mathrm{pH}$ from the organic layer down to $0.4 \mathrm{~m}$ depth, the decrease in soil $\mathrm{CO}_{2}$ efflux was not due to acidification and $\mathrm{pH}$-related changes in soil chemistry. The decline occurred simultaneously with an enhancement of stem diameter growth (Adamek et al., 2009a; Pame-Baldos, 2009), yielding reduced ratios of soil $\mathrm{CO}_{2}$ efflux to stem growth in the $\mathrm{N}$-addition plots (Fig. 6). This link, which hints at a shift in $\mathrm{C}$ partitioning from below- to aboveground, persisted throughout the study period and suggests that the decline in soil $\mathrm{CO}_{2}$ efflux was partly attributable to a decrease in rhizosphere respiration. The fact that $1.5-\mathrm{yr} \mathrm{N}$ addition did not affect fine root biomass, production or turnover in the organic layer and 0-0.2 m mineral soil (Adamek, 2009b) does not invalidate this implication because a reduction of root and root-associated respiration may also stem from a decline in the total belowground $\mathrm{C}$ allocation and rhizosphere C flux (Giardina et al., 2004) or a decrease in root colonization with mycorrhizal fungi (Treseder, 2004; Talbot et al., 2008). Also we do not have information about possible fine root responses that may have occurred after August 2007, or on coarse roots. A similar response as in our studied Panamanian forest has been found in a nutrient-limited tropical Eucalyptus plantation where fertilization (with $\mathrm{N}, \mathrm{P}$, potassium and micronutrients) increased wood productivity as well as total litterfall but decreased $\mathrm{C}$ allocation to fine roots and reduced soil $\mathrm{CO}_{2}$ efflux by $18 \%$ (Giardina et al., 2004). Also, a recent analysis of annual $\mathrm{C}$ budgets for 63 forest ecosystems from temperate, boreal and tropical regions strongly supported the assumption that enhanced nutrient availability generally increases $\mathrm{C}$ partitioning to aboveground net primary production -mainly to wood production- while it decreases partitioning to the total belowground $\mathrm{C}$ flux (Litton et al., 2007).

We can not exclude the possibility that, besides the shift in $\mathrm{C}$ partitioning from below to aboveground and a resulting diminution of rhizosphere respiration, microbial respiration may have decreased as well. Within the first two years of $\mathrm{N}$ addition the total fine litterfall was $\sim 1 \mathrm{MgC} \mathrm{ha}^{-1}$ larger in the $\mathrm{N}$-addition than the control plots (Adamek et al., 2009a), enlarging the substrate pool for decomposition. In this forest with restricted decomposition, however, the mean annual input of litterfall-C (4.3 $\left.\mathrm{MgC} \mathrm{ha}^{-1} \mathrm{yr}^{-1}\right)$ is small compared to the $\mathrm{C}$ stock in the organic layer $\left(\sim 25 \mathrm{MgCha}^{-1}\right)$. $\mathrm{N}$ addition reduced microbial biomass and activity of ligninolytic and cellulolytic enzymes in temperate forests with organic horizons (DeForest et al., 2004; Frey et al., 2004) and has been attributed to retard degradation of recalcitrant $\mathrm{C}$ fractions, thereby causing increases in the organic matter stock of forests (Berg and Meentemeyer, 2002). Further process-oriented studies (e.g. mycorrhizal association, microbial community composition, and enzyme activities) would greatly contribute to a deeper understanding of our observed changes in the montane forest's $\mathrm{C}$ cycling, and would elucidate to which extent the observed shift in $\mathrm{C}$ allocation explains the reduction in soil $\mathrm{CO}_{2}$ efflux. 


\section{Consequences of chronic $\mathrm{N}$ deposition on carbon cycling in tropical forests}

Biological demand for $\mathrm{N}$ (i.e. presence or absence of $\mathrm{N}$ limitation on vegetation growth) was an important qualitative predictor of the response of soil $\mathrm{CO}_{2}$ efflux to elevated soil $\mathrm{N}$ availability. For tropical lowland forests on soils with high nutrient-supplying and buffering capacity, where primary productivity is not $\mathrm{N}$-limited, we do not expect that chronic $\mathrm{N}$ addition will affect their $\mathrm{C}$ balance in the short term or on a decadal time scale. In tropical montane forests which have $\mathrm{N}$-limited primary productivity $\mathrm{N}$ addition might cause a reduction in soil $\mathrm{CO}_{2}$ efflux. Once $\mathrm{N}$ limitation is alleviated a relatively quick shift in $\mathrm{C}$ partitioning from belowto aboveground may occur. In the longer term, such shift would cause imprints on the magnitude of soil C storage. U1timately, soil $\mathrm{CO}_{2}$ efflux (and forest productivity) may eventually decline as $\mathrm{N}$ enrichment is accompanied by a progressing soil acidification and changing soil chemical traits. However -based on our results and baring in mind that our experimental $\mathrm{N}$-loading exceeded anticipated $\mathrm{N}$ deposition ratesthis condition may take many years to develop. The onset of a decrease in soil $\mathrm{CO}_{2}$ efflux will be strongly determined by the initial $\mathrm{N}$ status and soil characteristics of the forest (e.g. $\mathrm{pH}$, cation exchange capacity and base saturation) and the $\mathrm{N}$ loading.

Acknowledgements. We wish to thank S. Joseph Wright, the principal investigator of the lowland nutrient manipulation experiment, for hosting our study, data sharing, valuable discussion and support; James Dalling for his help during the selection of the montane forest site; Rodolfo Rojas, Carlos Sanchez, Ignacio Delcid, Olivier Gonzalez, Omar Hernandez, and Rufino Gonzalez for their dedicated assistance during field measurements; Norman Loftfield, Milton Garcia and Jaime Florez for their help with the equipment; Markus Adamek and Angelica Pame-Baldos for sharing their stem growth data; the Smithsonian Tropical Research Institute for extending excellent logistical and technical support; and the two referees and Kirsten Küsel for their thorough and helpful reviews. This study is under the NITROF project funded by the Robert Bosch Foundation (Germany) and awarded to M. D. Corre as independent research group leader.

Edited by: K. Küsel

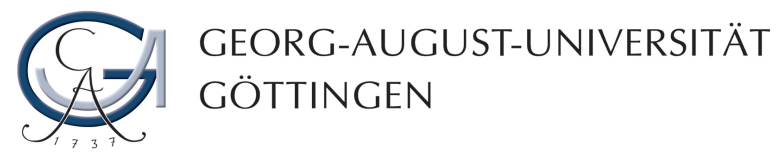

This Open Access Publication is funded by the University of Göttingen.

\section{References}

Adamek, M., Corre, M. D., and Hölscher, D.: Early effect of elevated nitrogen input on above-ground net primary production of a lower montane rain forest, Panama, J. Trop. Ecol., 25, 637-647, 2009a.

Adamek, M.: Effects of increased nitrogen input on the net primary production of a tropical lower montane rain forest, Panama, $\mathrm{Ph} . \mathrm{D}$. thesis, University of Goettingen, Goettingen, Germany, 2009b.

Berg, B. and Meentemeyer, V.: Litter quality in a north European transect versus carbon storage potential, Plant Soil, 242, 83-92, 2002.

Bowden, R. D., Davidson, E. A., Savage, K., Arabia, C., and Steudler, P. A.: Chronic nitrogen additions reduce total soil respiration and microbial respiration in temperate forest soils at the Harvard Forest, Forest. Ecol. Manag., 196, 43-56, 2004.

Breuer, L., Kiese, R., and Butterbach-Bahl, K.: Temperature and moisture effects on nitrification rates in tropical rain-forest soils, Soil Sci. Soc. Am. J., 66, 834-844, 2002.

Cavelier, J., Wright, S. J., and Santamaría, J.: Effects of irrigation on litterfall, fine root biomass and production in a semideciduous lowland forest in Panama, Plant Soil, 211, 207-213, 1999.

Cleveland, C., Reed, S. C., and Townsend, A. R.: Nutrient regulation of organic matter decomposition in a tropical rain forest, Ecology, 87, 492-503, 2006.

Cleveland, C. C. and Townsend, A. R.: Nutrient additions to a tropical rain forest drive substantial soil carbon dioxide losses to the atmosphere, P. Natl. A. Sci., 103, 10316-10321, 2006.

Cornejo, F. H., Varela, A., and Wright, S. J.: Tropical forest litter decomposition under seasonal drought: nutrient release, fungi and bacteria, Oikos, 70, 183-190, 1994.

Crawley, M. J.: Statistical Computing, An Introduction to Data Analysis using S-Plus, John Wiley \& Sons Ltd, Chichester, England, 2002.

Curiel Yuste, J., Janssens, I. A., Carrara, A., and Ceulemans, R.: Annual $\mathrm{Q}_{10}$ of soil respiration reflects plant phenological patterns as well as temperature sensitivity, Glob. Change Biol., 10, 161-169, 2004.

Davidson, E. A., Verchot, L. V., Cattânio, J. H., Ackerman, I. L., and Carvalho, J. E. M.: Effects of soil water content on soil respiration in forests and cattle pastures of eastern Amazonia, Biogeochemistry, 48, 53-69, 2000.

Davidson, E. A., Janssens, I. A., and Luo, Y.: On the variability of soil respiration in terrestrial ecosystems: moving beyond $\mathrm{Q}_{10}$, Glob. Change Biol., 12, 154-164, 2006.

DeForest, J. L., Zak, D. R., Pregitzer, K. S., and Burton, A. J.: Atmospheric nitrate deposition, microbial community composition, and enzyme activity in Northern Hardwood Forests, Soil Sci. Soc. Am. J., 68, 132-138, 2004.

Frey, S. D., Knorr, M., Parrent, J. L., and Simpson, R. T.: Chronic nitrogen enrichment affects the structure and function of the soil microbial community in temperate hardwood and pine forests, Forest Ecol. Manag., 196, 159-171, 2004.

Galloway, J. N., Aber, J. D., Erisman, J. W., Seizinger, S. P., Howarth, R. W., Cowling, E. B., and Cosby, B. J.: The Nitrogen Cascade, BioScience, 53, 341-356, 2003.

Galloway, J. N., Townsend, A. R., Erisman, J. W., Bekunda, M., Cai, Z., Freney, J. R., Martinelli, L. A., Seitzinger, S. P., and Sutton, M. A.: Transformation of the nitrogen cycle: recent trends, 
questions, and potential solutions, Science, 320, 889-892, 2008.

Giardina, C. P., Binkley, D., Ryan, M. G., Fownes, J. H., and Senock, R. S.: Belowground carbon cycling in a humid tropical forest decreases with fertilization, Oecologia, 139, 545-550, 2004.

Godbold, D. L., Fritz, E., and Hüttermann, A.: Aluminum toxicity and forest decline, P. Natl. A. Sci., 85, 3888-3892, 1988.

Grubb, P. J.: Control of forest growth and distribution on wet tropical mountains: with reference to mineral nutrition, Annu. Rev. Eco. Syst., 8, 83-107, 1977.

IPCC, Climate Change 2007: The Physical Science Basis. Contribution of Working Group I to the Fourth Assessment Report of the Intergovernmental Panel on Climate Change, Cambridge University Press, Cambridge and New York, 2007.

Jobbágy, E. G. and Jackson, R. B.: The vertical distribution of soil organic carbon and its relation to climate and vegetation, Ecol. Appl., 10, 423-436, 2000.

Kaspari, M., Garcia, M. N., Harms, K. E., Santana, M., Wright, S. J., and Yavitt, J. B.: Multiple nutrients limit litterfall and decomposition in a tropical forest, Ecol. Lett., 11, 35-43, 2008.

Koehler, B., Corre, M. D., Veldkamp, E., Wullaert, H., and Wright, S. J.: Immediate and long-term nitrogen oxide emissions from tropical forest soils exposed to elevated nitrogen input, Glob. Change Biol., 15, 2049-2066, 2009.

Kursar, T. A.: Evaluation of soil respiration and soil $\mathrm{CO}_{2}$ concentration in a lowland moist forest in Panama, Plant Soil, 113, 21-29, 1989.

Leigh, E. G., Rand, A. S., and Windsor, D. W.: The ecology of a tropical forest, Smithsonian Press, Washington DC, USA, 1996.

Likens, G. E., Driscoll, C. T., and Buso, B. C.: Long-term effects of acid rain: response and recovery of a forest ecosystem, Science, 272, 244-246, 1996.

Linn, D. M. and Doran, J. W.: Effect of water-filled pore space on carbon dioxide and nitrous oxide production in tilled and nontilled soils, Soil Sci. Soc. Am. J., 48, 1267-1272, 1984.

Litton, C. M., Raich, J. W., and Ryan, M. G.: Carbon allocation in forest ecosystems, Glob. Change Biol., 13, 2089-2109, 2007.

Livingston, G. P., Hutchinson, G. L., and Spartalian, K.: Trace gas emission in chambers: A non-steady-state diffusion model, Soil Sci. Soc. Am. J., 70, 1459-1469, 2006.

Loftfield, N., Flessa, H., Augustin, J., and Beese, F.: Automated gas chromatographic system for rapid analysis of the atmospheric trace gases methane, carbon dioxide, and nitrous oxide, J. Environ. Qual., 26, 560-564, 1997.

Lohse, K. A. and Matson, P. A.: Consequences of nitrogen additions for soil processes and solution losses from wet tropical forests, Ecol. Appl., 15, 1629-1648, 2005.

Luo, Y. and Zhou, X.: Soil respiration and the environment, Elsevier Academic Press, Burlington, San Diego and London, UK, 2006.

Malhi, Y.: The carbon balance of the tropical forest biome, in: The carbon balance of forest biomes, edited by: Griffiths, H., Jarvis, P. G. and Taylor \& Francis Group, Oxford, England, 217-234, 2005.

Mo, J., Brown, S., Xue, J., Fang, Y., and Li, Z.: Response of litter decomposition to simulated $\mathrm{N}$ deposition in disturbed, rehabilitated and mature forests in subtropical China, Plant Soil, 282, 135-151, 2006.

Mo, J., Zhang, W., Zhu, W., Gundersen, P., Fang, Y., Li, D., and Wang, H.: Nitrogen addition reduces soil respiration in a mature tropical forest in southern China, Glob. Change Biol., 14, 403412, 2008.

Nadelhoffer, K. J.: The potential effects of nitrogen deposition on fine-root production in forest ecosystems, New Phytol., 147, 131-139, 2000.

Neff, J. C., Townsend, A. R., Gleixner, G., Lehman, S. J., Tumbull, J., and Bowman, W. D.: Variable effects of nitrogen additions on the stability and turnover of soil carbon, Nature, 419, 915-917, 2002.

Norby, R. J. and Jackson, R. B.: Root dynamics and global change: seeking an ecosystem perspective, New Phytol., 147, 3-12, 2000.

Ostertag, R.: Effects of nitrogen and phosphorus availability on fine-root dynamics in Hawaiian montane forests, Ecology, 82, 485-499, 2001.

Pame-Baldos, A.: Above-ground net primary productivity and leaching losses in a tropical montane forest exposed to elevated nitrogen input, M.Sc. thesis, University of Goettingen, Goettingen, Germany, 2009.

Priess, J. and Fölster, H.: Microbial properties and soil respiration in submontane forests of Venezuelian Guyana: characteristics and response to fertilizer treatments, Soil Biol. Biochem., 33, 503509, 2001.

Raich, J. W.: Aboveground productivity and soil respiration in three Hawaiian rain forests, Forest Ecol. Manag., 107, 309-318, 1998.

Raich, J. W., Riley, R. H., and Vitousek, P. M.: Use of root-ingrowth cores to assess nutrient limitation in forest ecosystems, Can. J. Forest Res., 24, 2135-2138, 1994.

Raich, J. W. and Schlesinger, W. H.: The global carbon dioxide flux in soil respiration and its relationship to vegetation and climate, Tellus, 44, 81-99, 1992.

R Development Core Team: A language and environment for statistical computing. R Foundation for Statistical Computing, Vienna, http://www.R-project.org, 2009.

Schwendenmann, L., Veldkamp, E., Brenes, T., O’Brien, J. J., and Mackensen, J.: Spatial and temporal variation in soil $\mathrm{CO}_{2}$ efflux in an old-growth neotropical rain forest, La Selva, Costa Rica, Biogeochemistry, 64, 111-128, 2003.

Talbot, J. M., Allison, S. D., and Treseder, K. K.: Decomposers in disguise: mycorrhizal fungi as regulators of soil $\mathrm{C}$ dynamics in ecosystems under global change, Funct. Ecol., 22, 955-963, 2008.

Treseder, K. K.: A meta-analysis of mycorrhizal responses to nitrogen, phosphorus, and atmospheric $\mathrm{CO}_{2}$ in field studies, New Phytol., 164, 347-355, 2004.

Van Breemen, N., Mulder, J., and Driscoll, C. T.: Acidification and alkalinization of soils, Plant Soil, 75, 283-308, 1983.

Wagner, S. W., Reicosky, D. C., and Alessi, R. S.: Regression models for calculating gas fluxes measured with a closed chamber, Agron. J., 89, 279-284, 1997.

Yavitt, J. B. and Wright, S. J.: Drought and irrigation effects on fine root dynamics in a tropical moist forest, Panama, Biotropica, 33, 421-434, 2001.

Yavitt, J. B., Wright, S. J., and Kelman Wieder, R.: Seasonal drought and dry-season irrigation influence leaf-litter nutrients and soil enzymes in a moist, lowland forest in Panama, Austral Ecol., 29, 177-188, 2004. 